\title{
The Importance of Psychic Distance in the Internationalization Process of Polish Companies-Pilot Research Results
}

\author{
Aleksandra Olejnik-Nizielska \\ University of Economics Katowice, Katowice, Poland
}

\begin{abstract}
Research objectives presented in the article are of theoretical, methodological, and empirical nature. The theoretical aim of the article is to present the different approaches to conceptualization and operationalization of psychic distance. The methodological aim of the article is to show the pilot research results of quantitative research planned in future. The paper aims at presenting the results of testifying the questionnaire, especially reactions of the respondents on the level of difficulty of questions included in it. The empirical aim of the article is to present the perceptions of managers about the importance of psychic distance stimuli (differences in culture, differences in economic and political systems, as well as differences in mentality and geographic distance) in the process of Polish companies' internationalization. The paper is based on the critical literature overview and on the field research conducted on the sample of 18 Polish companies with the technique of direct interview. In the first part of the article, the research design as well as methodological issues connected with psychic distance measurement is presented. The second part of the article is dedicated to the field research results on the importance of psychic distance in the process of internationalization. The conclusions of the current stage of the research will comprise the base of complete research. The conducted research enabled the author to answer the following research questions: What is the impact of psychic distance stimuli on the process of Polish companies' internationalization (the directions and forms of internationalization, the pace and amount of countries subject to foreign expansion of Polish companies, and the value of sales and foreign capital engagement of Polish companies abroad)? What is the impact of psychic distance stimuli on managers' decisions connected with engagement on international markets (initiating business with foreign partners, leading business on international markets, and withdrawal business from international markets)? What are the factors determining perceptions of psychic distance by managers? What is the size of psychic distance among Poland and the foreign expansion markets of Polish companies? The respondents stated that the managers' perceptions about psychic distance importance in the process of companies' internationalization depend on the managers' experience in activity on international markets, the knowledge of managers about international markets, the level of education of managers, and the level of stability and changeability of environment, in which the company operates. According to the managers, the most important factors having impact on decisions connected with internationalization are: cultural differences (especially differences in religion), political differences (especially the level of democracy), geographic distance (the differences in time zones), the differences in economic systems (the level of economic development), and the differences in mentality (different way of thinking of managers). The factors having impact on companies'
\end{abstract}

Aleksandra Olejnik-Nizielska, Ph.D., International Management Department, Faculty of Management, University of Economics Katowice, Poland.

Correspondence concerning this article should be addressed to Aleksandra Olejnik-Nizielska, International Management Department, University of Economics Katowice, Bogucicka str. 14, 40-226 Katowice, Poland. 
engagement in international markets are: the level of democracy, the level of infrastructure development, different way of thinking of managers, and differences in time zones. The managers stated that the most significant differences in cultural systems are among Poland-China, Poland-Turkey, and Poland-Romania. The most significant differences in economic systems occur among Poland and the receivers of Polish export China, Ukraine, and the United States. The biggest differences in political systems are among Poland-China, Poland-Russia Belarus, and Poland-Ukraine. According to the managers, the biggest differences in mentality occur among Poland-China, Poland-Turkey, and Poland-the United States. Geographic distance is the most important factor in Polish export to the United States, China, Turkey, and Spain. There is applied a methodology stating that psychic distance (and its stimuli) should not be measured only with the use of objective constructs and statistical data, but also with the use of subjective data, such as the responses of decision makers of companies under internationalization. The value of the article is the presentation of the application of new research tool for psychic distance measurement.

Keywords: psychic distance, cultural differences, differences in economic and political systems, differences in mentality, geographic distance, companies' internationalization, pilot research

\section{Introduction}

Over the last few years, a number of publications have been dedicated to the internationalization of Polish companies. An increasing interest in this problem has also been spurred by the transformation of the political and economic system in Poland and the Poland's accession to the European Union.

Polish companies started internationalizing their activity more willingly. The managers built their foreign strategies based on marketing research and market analysis. Polish companies are more expansive and they more often reach foreign clients. They are also opening their foreign representatives more frequently. However, their foreign expansion is also connected with some difficulties. Polish managers have problems with verification of their foreign partners, they are afraid of competitiveness of the foreign markets, and they often do not have enough capital to exist on international markets.

One of barriers of internationalization of Polish companies is psychic distance. The concept of psychic distance was originally introduced by Beckerman in 1956, as an afterthought to a study on the impact of relative economic distance on trade patterns. Psychic distance was introduced as a subjective influence moderating the role of objective economic distance. At the beginning, however, no extensive research was conducted in order to analyze the impact of psychic distance on the choice of foreign markets. Subsequently, in the 1970s, this concept was further developed by Johanson and Vahlne (1977), the authors of the sequential model, as mentioned above. These economists from Uppsala University defined psychic distance as a set of factors preventing or disturbing the flow of information between the firm and the market (Johanson \& Vahlne, 1977; Johanson \& Wiedersheim, 1975). These difficulties may be directly related to communication with existing and potential customers. It has been stated that the internationalization process (as well as other international business transactions) is not only determined by objective economic realities, but is also influenced by the availability of information and by the decision-maker's cognitive capabilities (Carlson, 1974).

The Polish contribution to this subject includes a variety of narrowly focused studies concerning proposed changes in the ways Polish enterprises act on international markets. There has also been empirical research on Polish companies' internationalisation, including the studies on the importance of internationalisation as a company's strategic goal, the forms and directions of geographic expansion, and competitive advantages 
offered by Polish firms. However, the importance of psychic distance in the process of Polish companies' internationalization has not been identified yet. This problem is the subject of the author's research.

The aim of the research is to identify the importance of psychic distance in the process of Polish companies' internationalization. The most important issue here appears to be the impact that psychic distance dimensions may have on the forms and directions of Polish companies' foreign expansion, as well as the value of sales and capital engagement of such companies on foreign markets, the pace at which they internationalise, and the number of foreign markets into which they expand.

In order to solve this research problem, it is necessary to combine various research methods (so-called triangulation of methods). In the research on the impact of psychic distance on the process of Polish companies' internationalization, the following research methods and techniques are used: a critical review of literature on the subject, desk research, and field research carried out using the techniques of in depth interview and face-to-face interview. Up till now, three stages of the research have been conducted. They include: critical literature overview in the field of international marketing, international management, and international business; qualitative research with the use of depth interview technique on the sample of 13 companies. The next stage of research will be of quantitative nature: It will be conducted on the sample of 200 companies. The important step in research on the significance of psychic distance in companies' internationalization is testifying the questionnaire, especially the reactions of respondents on its complexity. That was the objective of presented pilot research.

The effect of the research will be the development of the psychic distance measurement methodology and the methodology for research into the impact of psychic distance on the process of companies' internationalization. The research will also result in a model for measuring the impact of psychic distance on decision-making process related to internationalization of Polish companies. The research results will be treated as a hint to managers, how to engage in international activity. The research results will contribute to the development of international activity of Polish managers and to development of cooperation with foreign partners.

\section{Theoretical Background}

The concept of psychic distance has attracted considerable research attention. It can be described as intriguing in that it represents a relatively simple, yet outstanding discriminator-useful for various purposes. The concept of psychic distance is based on the assumption that managers are less likely to initiate and/or pursue business relations with countries perceived to be dissimilar (Stottinger \& Schlegelmilch, 2000). Conversely, the lower the perceived psychic distance from a market, the more likely it is that business activities with this market will be expanded. Thus, firms are advised to initiate cooperation with closed markets in terms of psychic distance (Bilkey \& Tesar, 1977). This would also reduce their learning needs and accelerate their pace of globalization. From a managerial perspective, the concept of psychic distance appears to offer a variety of applications, e.g., in investigating the role of international experience in the choice of establishment mode (Dow \& Larimo, 2011). It could be used as a discriminator between managers with high and low psychic distance respectively, thus allowing for the more effective targeting of recipients when allocating export activities. Psychic distance also guides country selection decisions during the internationalization process (namely by addressing psychically close countries).

In management literature, cultural distance has been used as a key variable in strategy, management, organization behaviour, and human resource management. The construct has been applied to a multitude research question, from innovation and organizational transformation to foreign expansion and technology transfer. 
According to Dow and Karunaratna (2009), psychic distance is arguably one of the most fundamental constructs within the field of international business. Across the past four decades, it has been cited as an important predictor variable for:

- the decision to export (Fletcher \& Bohn, 1998; Holzmutter \& Kasper, 1990; Wiedersheim, Olson, \& Welch, 1978);

- market selection decisions - for both exporting (Dow, 2001; Johanson \& Vahlne, 1977) and foreign direct investment (Grosse \& Goldberg, 1991; Grosse \& Trevino, 1996);

- entry mode choices - concerning both the degree of control (K. D. Brouthers \& L. E. Brouthers, 2001; Chang \& Rosenzweig, 2001; Kogut \& Singh, 1988; Tihanyi, Griffith, \& Russel, 2005) and the use of acquisitions versus greenfield entries (K. D. Brouthers \& L. E. Brouthers, 2001; Harzing, 2002);

- the degree of adaptation in foreign markets (Dow, 2001; Sousa \& Bradley, 2008);

- a variety of other international phenomena (Boyacigiller, 1990; Shenkar, 2001).

The different approaches to conceptualization, operationalization, and measurement of psychic distance are presented in Table 1.

Table 1

Conceptualization, Operationalization, and Measurement Issues of Cultural and Psychic Distance

\begin{tabular}{|c|c|c|}
\hline \multicolumn{3}{|l|}{ Cultural distance } \\
\hline Author (year) & Conceptualization & Operationalization and measurement \\
\hline $\begin{array}{l}\text { Sousa and Bradley (2008); } \\
\text { Dow and Larimo (2009a; } \\
\text { 2009b); Kirkham, Lowe, } \\
\text { and Gibson (2006); } \\
\text { Tihanyi et al. (2005); and } \\
\text { Zhao, Luo, and Suh (2004) }\end{array}$ & $\begin{array}{l}\text { Differences between the culture } \\
\text { of one's own country and the } \\
\text { culture of a target country (e.g., } \\
\text { export destination country). It is } \\
\text { more objective in character-it } \\
\text { acknowledges the existing } \\
\text { cultural differences. }\end{array}$ & $\begin{array}{l}\text { Differences in Hofstede's, GLOBE, and Schwartz dimensions and } \\
\text { measurement with classic Kogut and Singh index: } \\
\qquad \mathrm{HCD}_{j}=\sum_{i=1}^{4}\left[\left(I_{i j}-I_{i K}\right)^{2} / V_{i}\right] \div 4 \\
\text { Where } \mathrm{HCD}_{\mathrm{j}} \text { is the cultural distance between country } j \text { and the } \\
\text { home country; } I_{i K} \text { is the score of the home country on this } \\
\text { dimension; and } V_{i} \text { is the variance of the score of the dimension. } \\
\qquad \mathrm{SchCD}_{j}=\sum_{i=1}^{3}\left[\left(I_{i j}-I_{i K}\right)^{2} / V_{i}\right] \div 3 \\
\text { Where SchCD } \mathrm{S}_{j} \text { is the cultural distance between country } j \text { and the } \\
\text { home country; } I_{i K} \text { is the score of the home country on this } \\
\text { dimension; and } V_{i} \text { is the variance of the score of the dimension. } \\
\qquad \mathrm{GCD}_{j}=\sum_{i=1}^{9}\left[\left(I_{i j}-I_{i K}\right)^{2} / P_{i}\right] \div 9 \\
\text { Where } \mathrm{GCD}_{j} \text { is the cultural distance between country } j \text { and the } \\
\text { home country; } I_{i K} \text { is the score of the home country in this } \\
\text { dimension; and } V_{i} \text { is the variance of the score of the dimension. } \\
\text { This index was prepared for nine GLOBE dimensions, based on } \\
\text { practices. } \\
\qquad \mathrm{GCD}_{j}=\sum_{i=1}^{9}\left[\left(I_{i j}-I_{i K}\right)^{2} / V_{i}\right] \div 9 \\
\text { Where } \mathrm{GCD}_{j} \text { is the cultural distance between country } j \text { and the } \\
\text { home country; } I_{i K} \text { is the score of the home country in this } \\
\text { dimension; and } V_{i} \text { is the variance of the score of the dimension. } \\
\text { This index was prepared for nine GLOBE dimensions, based on } \\
\text { values }\end{array}$ \\
\hline
\end{tabular}


Table 1 to be continued

\begin{tabular}{|c|c|c|}
\hline \multicolumn{3}{|l|}{ Psychic distance } \\
\hline Author (year) & Conceptualization & Operationalization and measurement \\
\hline $\begin{array}{l}\text { Johanson and Wiedersheim } \\
(1975)\end{array}$ & $\begin{array}{l}\text { The sum of factors preventing or } \\
\text { disturbing flows of information } \\
\text { between the firm and the market. }\end{array}$ & $\begin{array}{l}\text { Measurement with three groups of statistical items: } \\
\text { - characteristics of the target market (level of development and } \\
\text { education of the workforce); } \\
\text { - differences in culture and languages; } \\
\text { - trade relations. }\end{array}$ \\
\hline Klein and Roth (1990) & $\begin{array}{l}\text { Perceived difference between the } \\
\text { home market and the foreign } \\
\text { market. }\end{array}$ & $\begin{array}{l}\text { Measurement with the use of factual indicators, such as: } \\
\text { - language of the country; } \\
\text { - accepted business practices; } \\
\text { - economic environment; } \\
\text { - legal system; } \\
\text { - communication infrastructure. }\end{array}$ \\
\hline $\begin{array}{l}\text { Nordstrom and Vahlne } \\
\text { (1994) }\end{array}$ & $\begin{array}{l}\text { Factors preventing or limiting } \\
\text { firms learning about and } \\
\text { understanding a foreign } \\
\text { environment. }\end{array}$ & $\begin{array}{l}\text { Swedish managers were asked to place an index value between } 0 \\
\text { and } 100 \text { for } 22 \text { countries. The lowest index was placed on the } \\
\text { country perceived, in psychic distance terms, to be closest to } \\
\text { Sweden; the highest index value was attributed to the country } \\
\text { perceived to be the most distant. Subsequently, on the basis of } \\
\text { these data, the average index of psychic distance was calculated } \\
\text { for each of the } 22 \text { countries. }\end{array}$ \\
\hline $\begin{array}{l}\text { Shoham, Rose, and } \\
\text { Albaum (1995) }\end{array}$ & $\begin{array}{l}\text { Cultural distance is a summary } \\
\text { construct, which represents the } \\
\text { extent of perceived dissimilarity } \\
\text { on dimensions that have an effect } \\
\text { on how business is conducted. }\end{array}$ & $\begin{array}{l}\text { Measured by responses to the following request: "Describe the } \\
\text { general nature of the dissimilarity your company faces for its most } \\
\text { important products and markets in terms of differences in culture, } \\
\text { economic climate, and legal climate" (five-point scale). }\end{array}$ \\
\hline $\begin{array}{l}\text { Stottinger and } \\
\text { Schlegelmilch }(2000)\end{array}$ & $\begin{array}{l}\text { The perceived foreignness of } \\
\text { international markets. }\end{array}$ & $\begin{array}{l}\text { Respondents were asked to position a number of countries in a } \\
\text { space of concentric circles, such that the distances to the centre } \\
\text { (represented by the home country) would represent the } \\
\text { subjectively experienced foreignness towards those countries. }\end{array}$ \\
\hline Clark and Pugh (2001) & $\begin{array}{l}\text { The degree of difference of the } \\
\text { cultural cluster to which the } \\
\text { target foreign country belongs } \\
\text { from the cultural cluster to which } \\
\text { the home country belongs. }\end{array}$ & $\begin{array}{l}\text { They used a cluster concept of cultural distance by ordering the } \\
\text { clusters in terms of their degree of difference from the cluster of } \\
\text { the home country. }\end{array}$ \\
\hline Evans and Mavondo (2002) & $\begin{array}{l}\text { Perception and understanding of } \\
\text { the cultural and business } \\
\text { differences. }\end{array}$ & $\begin{array}{l}\text { Psychic distance comprises cultural distance and business } \\
\text { distance: } \\
\qquad \mathrm{CD}_{j} \text { or } \mathrm{BD}_{j}=\sum\left\{\left(I_{i j}-1\right) 2 / V_{i}\right\} / n \\
\text { Where } \mathrm{CD}_{j} \text { or } \mathrm{BD}_{j} \text { are the cultural or business differences of the } \\
\text { jth foreign market from the home market; } I_{i j} \text { stands for the index } \\
\text { for the } i \text {-th cultural or business dimension and the } j \text {-th market; } 1 \\
\text { signifies the home market; and } V_{i} \text { is the variance of the index of } \\
\text { the } i \text {-th dimension }\end{array}$ \\
\hline $\begin{array}{l}\text { Dow (2001); Dow and } \\
\text { Karunaratna (2006); Dow } \\
\text { and Larimo (2009b); and } \\
\text { Dow and Larimo (2011) }\end{array}$ & $\begin{array}{l}\text { Subjectively perceived distance } \\
\text { to a given country. } \\
\text { The individual perception of the } \\
\text { differences between the home } \\
\text { and the foreign country. } \\
\text { The psychic distance to a specific } \\
\text { foreign country is a reflection of } \\
\text { the perceiver's knowledge, } \\
\text { familiarity, and sense of } \\
\text { understanding. }\end{array}$ & $\begin{array}{l}\text { Psychic distance cannot be measured with factual indicators, such } \\
\text { as publicly available statistics. Measuring psychic distance at an } \\
\text { individual level, as the individual's perceptions of reality and } \\
\text { highly subjective opinions. } \\
\text { Dow and Karunaratna's approach (2006): } \\
\text { - a three-item scale measuring differences in language; } \\
\text { - a similarly constructed three-item scale measuring differences } \\
\text { in religion; a nine-item scale measuring differences in } \\
\text { industrial developments; } \\
\text { - a three-item scale measuring differences in education; } \\
\text { - a four-item scale measuring the differences in degree of } \\
\text { democracy, representing differences in political systems. }\end{array}$ \\
\hline
\end{tabular}


Table 1 to be continued

\begin{tabular}{|c|c|c|}
\hline $\begin{array}{l}\text { Sousa and Bradley (2005); } \\
\text { Sousa and Bradley (2006); } \\
\text { and Sousa and Lages } \\
(2011)\end{array}$ & $\begin{array}{l}\text { Individual's perception of the } \\
\text { differences between the home } \\
\text { country and the foreign country. }\end{array}$ & $\begin{array}{l}\text { - } \text { climatic conditions; } \\
\text { - } \text { purchasing power of customers; } \\
\text { - lifestyles; } \\
\text { - level of literacy and education; } \\
\text { - language; } \\
\text { - cultural values, beliefs, attitudes, and traditions; } \\
\text { - five-point scale. }\end{array}$ \\
\hline $\begin{array}{l}\text { Drogendijk and Slangen } \\
(2006)\end{array}$ & $\begin{array}{l}\text { Management team perception of } \\
\text { cultural differences. }\end{array}$ & $\begin{array}{l}\text { - differences in norms and values, habits, and customs, } \\
\text { behaviors; } \\
\text { - business practices and organization practice; } \\
\text { - language, ways of communicating, and relationship with } \\
\text { people between the home and the host countries. }\end{array}$ \\
\hline $\begin{array}{l}\text { Håkanson and Ambos } \\
(2010)\end{array}$ & $\begin{array}{l}\text { Johanson and Wiedersheim's } \\
\text { definition (1975). }\end{array}$ & $\begin{array}{l}\text { Factors of psychic distance: geographic distance, linguistic } \\
\text { differences, and political and economic differences. }\end{array}$ \\
\hline
\end{tabular}

Source: Own elaboration on the base of literature review.

\section{Research Design}

As previously mentioned, the research conducted by the author focused on the investigation of the impact of overall psychic distance and psychic distance factors, in the process of Polish companies' entry into international markets.

While investigating individual psychic distance of a manager with reference to a host country, i.e., a particular person to a particular foreign market, it is possible to state that the perceptions of distance are determined by the features of managers, characteristic of companies, and environmental factors. It should be also noticed that perceptions of distance change in time.

To solve the above mentioned research problem, the following questions should be answered:

(1) What are the perceptions of managers about psychic distance and its stimuli (cultural differences, differences in economic and political systems, and differences in mentality and geographic distance) between Poland and markets of foreign expansion of Polish companies?

(2) What is the impact of psychic distance stimuli on the process of Polish companies' internationalization (directions and forms of internationalization, the pace and amount of countries subject to foreign expansion of Polish companies, and the value of sales and foreign capital engagement)?

(3) What is the impact of psychic distance stimuli on managers' decisions connected with engagement on international markets (initiating business with foreign partners, leading business on international markets, and withdrawal business from international markets)?

(4) What are the factors determining perceptions of psychic distance by managers?

(5) What is the size of psychic distance among Poland and the foreign expansion markets of Polish companies?

The main objective of the research is to identify the impact of psychic distance on managers' decisions connected with the process of Polish companies' internationalization. It is of crucial importance to investigate the impact of psychic distance dimensions on forms and directions of foreign expansion of Polish companies, as well as the value of sales and foreign capital engagement of these entities, pace of internationalization, and amount of foreign markets of expansion.

The cognitive objectives of the research are as follows: 
- The measurement of perceived psychic distance (the subjective opinions of Polish managers about the factors disturbing or blocking the flow of information among markets);

- The identification of the overall impact of psychic distance on the choice of directions of foreign expansion and entry strategies chosen by Polish companies;

- The identification of the overall impact of psychic distance on the pace of foreign expansion and the number of target countries for Polish companies;

- The identification of the overall impact of psychic distance on the value of sales and foreign capital engagement of Polish companies abroad;

- The identification of factors having impact on managerial perceptions of psychic distance.

\section{Hypotheses}

The following research hypotheses are formulated with reference to the objectives listed above.

\section{Main Hypothesis}

A hypothesis has been established that the psychic distance between Poland and foreign markets of Polish companies' expansion is an important determinant for the decision-making process related to Polish companies' internationalization. It determines the choice of directions and the level of Polish companies' involvement in foreign operations, as well as the value of sales and capital engagement of such companies on foreign markets, the pace at which they internationalise, and the number of foreign markets into which they expand.

\section{Detailed Hypotheses}

H1: Polish managers classify cultural differences and the differences in political and economic social systems as the main factors disturbing the flow of information among the markets;

H2: Polish companies tend to choose, as their expansion targets, countries with low psychic distance, even if the geographic distance is high. While entering foreign markets with high psychic distance, Polish companies choose entry modes with low level of control and capital engagement. While entering foreign markets with low psychic distance, Polish companies choose entry modes with high level of control and capital engagement;

H3: As psychic distance between Poland and foreign markets of Polish companies' expansion diminishes, the pace of Polish companies' expansion and the number of target foreign markets grow;

H4: As psychic distance between Poland and foreign markets of Polish companies' expansion diminishes, the amount of sales generated and capital engaged by Polish companies grows;

H5: The most important factors having impact on perceptions of psychic distance are the features of managers, their experience in activity on international markets, and their knowledge about international markets and education.

\section{Sampling}

For both qualitative and quantitative methods, a purposive sample will be chosen:

- Qualitative research-13 companies (already conducted);

- Quantitative research-200 companies.

The sample consists of Polish companies. The list of companies and the subjects of the research were created on the base of the general knowledge of the researcher and the lists and rankings of Polish exporters: rankings of Ministry of Economy: "Sława Polski", "Orzeł Eksportu", and "Dobra firma"; ranking of the most significant Polish companies "Lista 500" Polityki; the list of "Stowarzyszenie Eksporterów Polskich"; or the 
ranking of Polish companies "Liderzy Eksportu".

In order to fulfill the above mentioned research objectives, it is necessary to combine different research methods and techniques (triangulation of methods and mixed method). According to this approach, the researcher collected and analysed data and concluded using different methods. On one side, this increases opportunities for verification of information obtained as a result of the very method. On the other side, this method frequently contributes to obtaining new diversified information. The above information results in generation of higher result accuracy (that results from convergence of research results are obtained by means of different but often complementary research methods).

Up till now, some research objectives and tasks have been realized. They are followings:

(1) Critical literature overview: identification of the role which specific theories and models of internationalization ascribe to psychic distance; analysis of the results of empirical research on the importance of psychic distance in the process of companies' internationalization;

(2) Elaboration of the methodology of the research on psychic distance: conceptualization and operationalization of psychic distance phenomenon and critical review of its measurement methods and techniques;

(3) Quantitative research: construction of the instructions to depth interviews, realization of the research in the field, and analysis of the qualitative data.

The next stage of the research will be of quantitative nature. It will be conducted on the sample of 200 companies. The article presents the results of pilot research conducted on the sample of 18 companies with the CATI technique.

\section{Research Results}

There were 18 companies under evaluation. One company was micro (hiring less than 10 workers), two companies were small (hiring from 11 to 50 workers), six companies were medium (hiring from 51 to 250 workers), and two companies were big (hiring more than 250 employees). The companies were divided into high and low technology industry: Seven companies under research were representing high technology industry; and four companies under research were representing low technology industry. Eight companies under research had $100 \%$ Polish capital and three companies under research had mixed capital.

The aim of the pilot research was to test the respondents' reactions on the questions from the questionnaire, the length of the questionnaire, and on the chosen research technique.

It is agreed that for the quality of the research, it should be conducted with the technique of the direct interview. It would enable the interviewer to have better interaction with the respondent and possibility of explaining the questions.

The respondents were asked about the significance of psychic distance in the process of Polish companies' internationalization. Most of the respondents agreed that psychic distance exists. According to the 14 respondents, psychic distance exists and has significant impact on the process of companies' internationalization. According to two of the respondents, psychic distance exists, but it has no significant impact on the process of companies' internationalization. Only one of the respondents stated that psychic distance does not exist. One of the respondents did not have opinion about the existence of psychic distance (Table 2). 
Table 2

The Statements of the Respondents About the Impact of Psychic Distance on the Process of Companies' Internationalization

\begin{tabular}{ll}
\hline Statements & Number of respondents \\
\hline Psychic distance exists and has a small impact on the process of companies' internationalization & 14 \\
Psychic distance exists, but it has a significant impact on the process of companies internationalization & 2 \\
Psychic distance does not exist & 1 \\
I have no opinion & 1 \\
\hline
\end{tabular}

Source: Own research.

The respondents were also asked to evaluate on the Likert scale their opinions about perceptions of psychic distance. Ten of the respondents agree with the statement that perceptions of psychic distance depend on factors like: the international experience of managers, the knowledge of managers about international markets, the education of managers, the stability, and changeability of the environment, in which the company operates. The $2 / 3$ managers agree with the statement that the perception of psychic distance depends on the value of export and capital engagement on international markets and on the complexity of the environment in which the company operates. Seven of the respondents agree with the statement that the perceptions of psychic distance depend on the mentality of managers and on the consumer characteristics on international markets. Six of the respondents evaluate also positively the dependence among psychic distance and features like: industry in which the company operates, the size of the company, and the characteristic of partners on international markets. Only five of managers state that the perceptions of psychic distance depend on the amount of years the company is present on international markets and on the psychological features of managers (Table 3 ).

The respondents were also asked to evaluate the importance of cultural factors on the managers decisions connected with internationalization (Table 4).

The most significant impact on decisions connected with internationalization has differences in religion. According to the managers, they are the most important in taking decisions about the choice of directions of foreign expansion (the average of respondents' answers is 3.61) and on the value of export (the average of respondents' answers is 3.44). The differences in values and norms have the most significant impact on the choice of directions of foreign expansion and the value of capital engagement of the foreign market (the average of respondents' answers is 3.39). In turn, the differences in languages have the most significant impact on the amount of countries subject to foreign expansion (the average of respondents' answers is 2.94).

The managers were evaluating the role of political factors in taking decisions about companies' internationalization. The level of democracy is the most important factor in taking decisions about the choice of directions of foreign expansion (the average of respondents' answers is 4.24) and the value of capital engagement in foreign markets (the average of respondents' answers is 4.00). Political stability is the most important factor in taking decisions about the choice of market entry strategy (the average of respondents' answers is 3.69) and the amount of countries subject to foreign expansion (the average of respondents' answers is 3.63).

The next criteria important in taking decisions about companies' internationalization are differences in economic systems. The level of economic development (measured by GDP per capita) has the most important impact on the amount of countries subject to foreign expansion. The level of infrastructure development is the most important factor in taking decisions about the value of export (the average is 3.67) and the choice of directions and market entry strategies (the average of respondents' answers is 3.67). 
Table 3

The Features Having Impact on Managerial Perceptions of Psychic Distance (No. of Respondents)

\begin{tabular}{|c|c|c|c|c|c|}
\hline Statements & $\begin{array}{l}\text { I completely } \\
\text { agree }\end{array}$ & I agree & $\begin{array}{l}\text { I neither agree } \\
\text { nor disagree }\end{array}$ & I disagree & $\begin{array}{l}\text { I totally } \\
\text { disagree }\end{array}$ \\
\hline $\begin{array}{l}\text { The perception of psychic distance depends on the } \\
\text { industry the company operates }\end{array}$ & & 6 & 3 & 2 & 0 \\
\hline $\begin{array}{l}\text { The perception of psychic distance depends on the size of } \\
\text { the company }\end{array}$ & & 6 & 1 & 5 & 0 \\
\hline $\begin{array}{l}\text { The perception of psychic distance depends on the value } \\
\text { of export and capital engagement on international markets }\end{array}$ & & 9 & 2 & 2 & 0 \\
\hline $\begin{array}{l}\text { The perception of psychic distance depends on the amount } \\
\text { of years the company is present on international markets }\end{array}$ & & 5 & 6 & 0 & 1 \\
\hline $\begin{array}{l}\text { The perception of psychic distance depends on the origin } \\
\text { of the capital of company ( } 100 \% \text { Polish or mixed capital) }\end{array}$ & & 3 & 7 & 1 & 1 \\
\hline $\begin{array}{l}\text { The perception of psychic distance depends on the } \\
\text { psychological features of managers }\end{array}$ & & 5 & 1 & 4 & 0 \\
\hline $\begin{array}{l}\text { The perception of psychic distance depends on the } \\
\text { international experience of managers }\end{array}$ & & 10 & 1 & 0 & 1 \\
\hline $\begin{array}{l}\text { The perception of psychic distance depends on the } \\
\text { knowledge of managers about international markets }\end{array}$ & & 10 & 1 & 0 & 1 \\
\hline $\begin{array}{l}\text { The perception of psychic distance depends on the } \\
\text { education of managers }\end{array}$ & & 10 & 2 & 0 & 0 \\
\hline $\begin{array}{l}\text { The perception of psychic distance depends on the } \\
\text { mentality of managers (national/global) }\end{array}$ & & 7 & 3 & 0 & 0 \\
\hline $\begin{array}{l}\text { The perception of psychic distance depends on the } \\
\text { complexity of the environment the company operates }\end{array}$ & & 9 & 3 & 0 & 0 \\
\hline $\begin{array}{l}\text { The perception of psychic distance depends on the } \\
\text { steadiness/changeability of the environment, in which } \\
\text { the company operates }\end{array}$ & & 10 & 1 & 2 & 0 \\
\hline $\begin{array}{l}\text { The perception of psychic distance depends on the } \\
\text { character of competition on international markets }\end{array}$ & & 3 & 5 & 2 & 1 \\
\hline $\begin{array}{l}\text { The perception of psychic distance depends on the } \\
\text { characteristics of partners on international markets } \\
\text { of the company }\end{array}$ & 3 & 6 & 3 & 1 & 0 \\
\hline $\begin{array}{l}\text { The perception of psychic distance depends on the } \\
\text { consumer characteristic on international markets }\end{array}$ & & 7 & 4 & 0 & 0 \\
\hline
\end{tabular}

Source: Own research.

Another factor being taken into consideration while making decisions about internationalization is the differences in mentality. The different way of thinking of managers has the most significant impact on the choice of market entry strategy (the average of respondents' answers is 3.71) and on the choice of directions of foreign expansion (the average of respondents' answers is 3.57). The manager's attitude to reality is the most important criteria in taking decisions about the choice of directions of foreign expansion and the choice of market entry strategy (the average is 3.43). The rules, with which the entity is heading during processing information from the market environment, are the most important criteria in taking decision about the choice of market entry strategy (the average of respondents' answers is 3.29) and the choice of directions of foreign expansion (the average of respondents' answers is 3.14).

The managers were asked to grade the importance of geographic distance in taking decisions about entering foreign markets. The differences in time zones are the most important criteria in taking decisions about the choice of directions of foreign expansion (the average is 4.21), the amount of countries subject to foreign expansion and the value of export (the average is 3.93). The distance in kilometers is the most important criteria 
in taking decisions about the amount of countries subject to foreign expansion (the average of respondents' answers is 3.93).

Table 4

The Importance of Psychic Distance Factors in Managerial Decisions About Internationalization

\begin{tabular}{|c|c|c|c|c|c|c|}
\hline Factors & $\begin{array}{l}\text { The choice of } \\
\text { directions of } \\
\text { foreign } \\
\text { expansion }\end{array}$ & $\begin{array}{l}\text { The choice of } \\
\text { market entry } \\
\text { strategy }\end{array}$ & $\begin{array}{l}\text { The amount of } \\
\text { countries } \\
\text { subject to } \\
\text { foreign } \\
\text { expansion }\end{array}$ & $\begin{array}{l}\text { The pace of } \\
\text { internationalization }\end{array}$ & $\begin{array}{l}\text { The value of } \\
\text { export }\end{array}$ & $\begin{array}{l}\text { The value } \\
\text { f capital } \\
\text { engagement in } \\
\text { foreign markets }\end{array}$ \\
\hline \multicolumn{7}{|l|}{ Cultural differences } \\
\hline Different values and norms & 3.39 & 3.28 & 2.89 & 2.81 & 3.17 & 3.39 \\
\hline Differences in religion & 3.61 & 3.17 & 3.17 & 3.39 & 3.44 & 3.33 \\
\hline Differences in languages & 2.94 & 2.83 & 2.78 & 2.50 & 2.72 & 2.78 \\
\hline \multicolumn{7}{|c|}{ Differences in political systems } \\
\hline $\begin{array}{l}\text { The role of the government } \\
\text { in the country }\end{array}$ & 3.41 & 3.59 & 2.88 & 2.88 & 3.12 & 3.47 \\
\hline The level of democracy & 4.24 & 3.94 & 3.94 & 3.81 & 3.76 & 4.00 \\
\hline Political stability & 3.53 & 3.69 & 3.63 & 3.38 & 3.50 & 3.44 \\
\hline \multicolumn{7}{|c|}{ Differences in economic systems } \\
\hline $\begin{array}{l}\text { The level of economic } \\
\text { development (measured by } \\
\text { GDP per capita) }\end{array}$ & 3.93 & 3.40 & 4.58 & 3.27 & 3.67 & 3.20 \\
\hline $\begin{array}{l}\text { The level of infrastructure } \\
\text { development }\end{array}$ & 3.60 & 3.60 & 3.07 & 2.93 & 3.67 & 3.40 \\
\hline $\begin{array}{l}\text { Situation on the labour } \\
\text { market in the region }\end{array}$ & 3.20 & 3.00 & 3.07 & 3.13 & 3.07 & 2.80 \\
\hline \multicolumn{7}{|l|}{ Differences in mentality } \\
\hline $\begin{array}{l}\text { Different way of thinking of } \\
\text { managers }\end{array}$ & 3.57 & 3.71 & 3.36 & 3.14 & 3.07 & 3.14 \\
\hline $\begin{array}{l}\text { The manager's attitude to } \\
\text { the reality }\end{array}$ & 3.43 & 3.43 & 3.21 & 2.71 & 3.14 & 3.14 \\
\hline $\begin{array}{l}\text { The rules with which the } \\
\text { entity is heading during } \\
\text { processing information from } \\
\text { the market/environment }\end{array}$ & 3.14 & 3.29 & 2.86 & 2.71 & 2.79 & 3.00 \\
\hline \multicolumn{7}{|l|}{ Geographic distance } \\
\hline Distance in kilometers & 3.57 & 3.21 & 3.93 & 3.36 & 3.57 & 3.50 \\
\hline Transportation costs & 2.86 & 2.93 & 2.57 & 2.64 & 2.57 & 2.36 \\
\hline Differences in time zones & 4.21 & 3.50 & 3.93 & 3.29 & 3.93 & 3.71 \\
\hline
\end{tabular}

Source: Own research.

The managers were also rating the impact of differences in cultures, differences in economic and political systems, as well as differences in mentality and geographic distance on activity of Polish companies on international markets (Table 5). The research results show that all the above mentioned factors have more significant impact on initiating and leading business abroad than that on withdrawal from foreign markets.

The most significant impact on initiating business with foreign partners has factors like: the level of democracy (the average of respondents' answers is 4.06), the role of the government in the country (the average of respondents' answers is 3.73), different way of thinking of managers (the average of respondents' answers is 3.71), and differences in time zones (the average of respondents' answers is 3.71). 
The respondents were indicating factors having impact on leading business with foreign partners. These are: level of democracy (the average of respondents' answers is 4.13), differences in time zones (the average of respondents' answers is 4.08), and different way of thinking of managers and distance among countries in kilometers (the average of respondents' answers is 3.64).

Similar factors are taking in consideration while taking decisions about withdrawal from foreign markets. These are: the level of democracy (the average is 3.63), differences in time zones (the average is 3.54), and different way of thinking of managers (the average is 3.50 ).

Table 5

The Importance of Psychic Distance Factors in Managerial Decisions About International Business Activity

\begin{tabular}{|c|c|c|c|}
\hline Factors & $\begin{array}{l}\text { Initiating business with } \\
\text { foreign partners }\end{array}$ & $\begin{array}{l}\text { Leading business with } \\
\text { foreign partners }\end{array}$ & $\begin{array}{l}\text { Withdrawal of business } \\
\text { from the certain market }\end{array}$ \\
\hline \multicolumn{4}{|l|}{ Cultural differences } \\
\hline Different values and norms & 3.06 & 3.39 & 2.94 \\
\hline Differences in religion & 3.11 & 3.11 & 2.56 \\
\hline Differences in languages & 2.76 & 2.71 & 2.35 \\
\hline \multicolumn{4}{|l|}{ Differences in political systems } \\
\hline The role of the government in the country & 3.73 & 3.50 & 3.06 \\
\hline The level of democracy & 4.06 & 4.13 & 3.63 \\
\hline Political stability & 3.44 & 3.50 & 3.38 \\
\hline \multicolumn{4}{|l|}{ Differences in economic systems } \\
\hline $\begin{array}{l}\text { The level of economic development } \\
\text { (measured by GDP per capita) }\end{array}$ & 3.36 & 3.00 & 2.86 \\
\hline The level of infrastructure development & 3.43 & 3.50 & 2.79 \\
\hline Situation on the labour market in the region & 2.86 & 2.36 & 2.57 \\
\hline \multicolumn{4}{|l|}{ Differences in mentality } \\
\hline Different way of thinking of managers & 3.71 & 3.64 & 3.50 \\
\hline The manager's attitude to the reality & 3.57 & 3.57 & 3.29 \\
\hline $\begin{array}{l}\text { The rules with which the entity is heading } \\
\text { during processing information from the } \\
\text { market/environment }\end{array}$ & 3.54 & 3.57 & 3.00 \\
\hline \multicolumn{4}{|l|}{ Geographic distance } \\
\hline Distance in kilometers & 3.57 & 3.64 & 3.00 \\
\hline Number of continents the company is present & 2.71 & 3.00 & 2.43 \\
\hline Time zone & 3.71 & 4.08 & 3.54 \\
\hline
\end{tabular}

Source: Own research.

The respondents were asked to enumerate countries "far away" from Poland taking into consideration the different psychic distance factors. Taking into considerations the differences in national cultures, the countries "far away" to Poland are India, Japan, China, and Saudi Arabia. Taking into consideration the differences in economic systems, the countries "far away" from Poland are Japan and China. The countries most "far away" from Poland taking into consideration differences in political systems are Egypt, the other Arabic countries, China, Saudi Arabia, Malaysia, Bangladesh, Sri Lanka, Indie, Peru, North Korea, and Iran. Taking into consideration the differences in mentality, the countries most "far away" from Poland are China, Japan, African countries, South Africa, Algiers, North Korea, Saudi Arabia, India, and Iran. The last factor of psychic distance is geographic distance. Countries "far away" from Poland taking into consideration these criteria are Japan, Australia, New Zealand, China, the USA, Malaysia, Singapore, and South Korea (Table 6). 
Table 6

Countries "Far Away" From Poland Taking Into Consideration the Different Psychic Distance Factors (No. of Respondents)

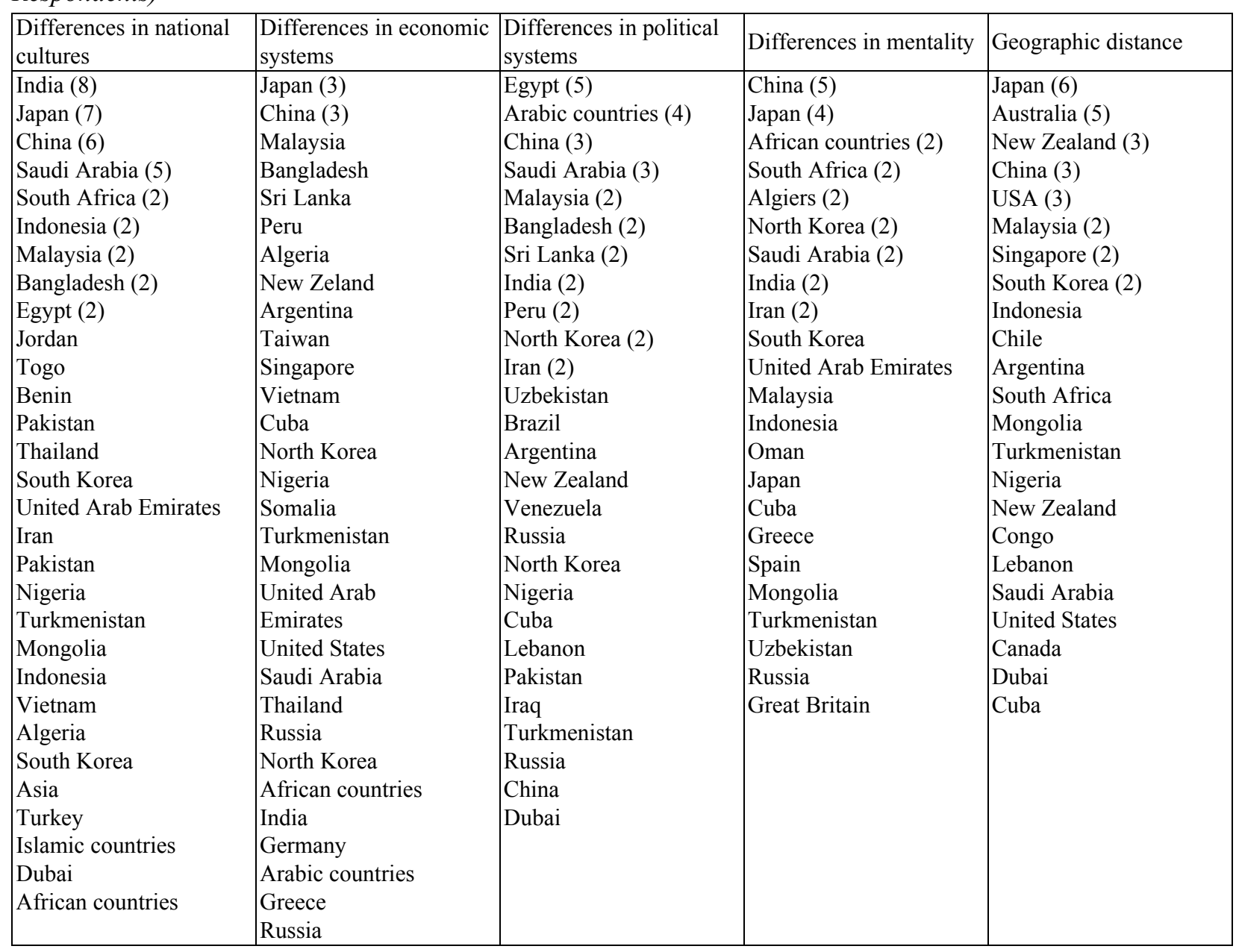

Source: Own research.

The respondents were enumerating countries "close" to Poland taking into consideration psychic distance factors (Table 7). The countries closest to Poland considering the differences in national cultures are Czech Republic, Ukraine, Slovakia, Germany, Russia, Great Britain, Belarus, and Hungary. Taking into consideration the differences in economic systems, the countries close to Poland are Germany, Czech Republic, Slovakia, France, Hungary, Ukraine, and Estonia. Considering the differences in political systems, the countries close to Poland are France, Germany, Czech Republic, Slovakia, Hungary, and Ukraine. With the view to differences in mentality, the countries closest to Poland are Czech Republic, Germany, Russia, Slovakia, Ukraine, and Great Britain. The last factor evaluated by the respondents was geographic distance. The countries closest to Poland taking into consideration this criteria are Czech Republic, Germany, Ukraine, Russia, Slovakia, Sweden, and Belarus.

The next question directed to the respondents was about evaluating the importance of psychic distance factors between Poland and the most significant receivers of Polish export.

The most significant differences in cultural systems are among Poland-China (the average of respondents' 
answers is 4.27), Poland-Turkey (the average of respondents' answers is 3.36), Poland-Romania (the average of respondents' answers is 3.00), Poland-Norway (the average of respondents' answers is 2.82), Poland-Spain and Poland-the United States (the average of respondents' answers is 2.64), Poland-Switzerland (the average of respondents' answers is 2.45), Poland-the Netherlands (the average of respondents' answers is 2.33), and Poland-France (the average of respondents' answers is 2.00 ).

Table 7

Countries "Close" to Poland Taking Into Consideration the Different Psychic Distance Factors

\begin{tabular}{|c|c|c|c|c|}
\hline $\begin{array}{l}\text { Differences in national } \\
\text { cultures }\end{array}$ & $\begin{array}{l}\text { Differences in economic } \\
\text { systems }\end{array}$ & $\begin{array}{l}\text { Differences in political } \\
\text { systems }\end{array}$ & Differences in mentality & Geographic distance \\
\hline $\begin{array}{l}\text { Ukraine (14) } \\
\text { Czech Republic (11) } \\
\text { Slovakia (8) } \\
\text { Germany (6) } \\
\text { Russia (4) } \\
\text { Great Britain (3) } \\
\text { Belarus (3) } \\
\text { Hungary (3) } \\
\text { Algeria (2) } \\
\text { Georgia (2) } \\
\text { Latvia (2) } \\
\text { Italy (2) } \\
\text { France } \\
\text { Ukraine } \\
\text { Switzerland } \\
\text { Romania } \\
\text { Spain }\end{array}$ & $\begin{array}{l}\text { Germany (10) } \\
\text { Czech Republic (9) } \\
\text { Slovakia (6) } \\
\text { France (5) } \\
\text { Hungary (4) } \\
\text { Ukraine (3) } \\
\text { Esthonia (3) } \\
\text { Russia (2) } \\
\text { Belarus (2) } \\
\text { Sweden (2) } \\
\text { Austria (2) } \\
\text { The Netherlands } \\
\text { Latvia } \\
\text { Lithuania } \\
\text { Great Britain } \\
\text { Spain } \\
\text { Romania }\end{array}$ & $\begin{array}{l}\text { France (8) } \\
\text { Germany (7) } \\
\text { Czech Republic (6) } \\
\text { Slovakia (6) } \\
\text { Hungary (5) } \\
\text { Ukraine (4) } \\
\text { Lithuania (3) } \\
\text { Russia (2) } \\
\text { Belarus (2) } \\
\text { Great Britain (2) } \\
\text { Italy (2) } \\
\text { Latvia } \\
\text { Spain } \\
\text { Belgium } \\
\text { Austria } \\
\text { Sweden } \\
\text { The Netherlands } \\
\text { Romania }\end{array}$ & $\begin{array}{l}\text { Czech Republic (8) } \\
\text { Germany (6) } \\
\text { Russia (6) } \\
\text { Slovakia (4) } \\
\text { Ukraine (3) } \\
\text { Great Britain (3) } \\
\text { France (2) } \\
\text { Hungary (2) } \\
\text { Latvia (2) } \\
\text { Lithuania } \\
\text { Ukraine } \\
\text { Norway } \\
\text { Austria } \\
\text { Slovenia } \\
\text { Croatia } \\
\text { Spain } \\
\text { Italy } \\
\text { Sweden } \\
\text { The Netherlands } \\
\text { Arabic countries } \\
\text { China } \\
\text { Vietnam } \\
\text { Japan } \\
\text { Turkey }\end{array}$ & $\begin{array}{l}\text { Czech Republic (9) } \\
\text { Germany (9) } \\
\text { Ukraine (9) } \\
\text { Russia (5) } \\
\text { Slovakia (5) } \\
\text { Sweden (4) } \\
\text { Belarus (3) } \\
\text { Estonia (2) } \\
\text { Slovakia (2) } \\
\text { Austria (2) } \\
\text { The Netherlands (2) } \\
\text { Bulgaria } \\
\text { Greece } \\
\text { Lithuania } \\
\text { Belgium }\end{array}$ \\
\hline
\end{tabular}

Source: Own research.

According to the managers, the most significant differences in economic systems among Poland and the receivers of Polish export are China (the average of respondents' answers is 3.55), Ukraine and the United States (the average of respondents' answers 3.09), Sweden (the average of respondents' answers is 2.75), Norway (the average of respondents' answers is 2.73), Finland (the average of respondents' answers is 2.65), Austria and Belarus (the average of respondents' answers is 2.64), Spain (the average of respondents' answers is 2.45), and Great Britain, Russia, and the Netherlands (the average of respondents' answers is 2.42).

The next stimuli of psychic distance are differences in political systems. According to the respondents, the biggest differences in political systems are among Poland-China (the average of respondents' answers is 4.00), Poland-Russia (the average of respondents' answers is 3.42), Poland-Belarus (the average of respondents' answers is 3.27), Poland-Ukraine (the average of respondents' answers is 3.09), and Poland-Turkey (the average of respondents' answers is 3.00). The differences in political systems are also important factors in Polish cooperation with Spain (the average of respondents' answers is 2.73), Russia (the average of respondents' answers is 2.55), Germany (the average of respondents' answers is 2.50), and the Netherlands and France (the average of respondents' answers is 2.33 ). 
The respondents evaluated also the role of the differences in mentality in the process of internationalization between Poland and the major receivers of Polish export. According to the managers, the biggest differences in mentality are among Poland-China (the average of respondents' answers is 3.36), Poland-Turkey (the average of respondents' answers is 3.27), Poland-the United States (the average of respondents' answers is 3.18), Poland-Romania and Poland-Ukraine (the average of respondents' answers is 3.00), Poland-Russia (the average of respondents' answers is 2.55), Poland-Germany (the average of respondents' answers is 2.50), Poland-Norway and Poland-Finland (the average of respondents' answers is 2.45), Poland-Sweden, Poland-Austria, and Poland-Belarus (the average of respondents' answers is 2.36), and Poland-Italy (the average of respondents' answers is 2.33).

The managers were also asked to evaluate the importance of geographic distance in Polish foreign trade. According to the respondents, geographic distance is the most important factor in Polish export to the United States and China (the average of respondents' answers is 4.36), Turkey (the average of respondents' answers is 3.18), Spain (the average of respondents' answers is 2.73), Norway (the average of respondents' answers is 2.45), Switzerland (the average of respondents' answers is 2.36), as well as Russia and Sweden (the average of respondents' answers is 2.27) (Table 8).

Table 8

Perceived Psychic Distance Between Poland and Foreign Expansion Markets of Polish Companies-The Most Significant Receivers of Polish Export (the Average of Respondents' Answers)

\begin{tabular}{|c|c|c|c|c|c|}
\hline \multirow[b]{2}{*}{ Specification } & \multicolumn{5}{|c|}{ Psychic distance factors } \\
\hline & $\begin{array}{l}\text { Differences in } \\
\text { culture }\end{array}$ & $\begin{array}{l}\text { Differences in } \\
\text { economics systems }\end{array}$ & $\begin{array}{l}\text { Differences in } \\
\text { political systems }\end{array}$ & $\begin{array}{l}\text { Differences in } \\
\text { managers' mentality }\end{array}$ & Geographic distance \\
\hline Germany & 1.50 & 2.25 & 2.00 & 2.50 & 1.50 \\
\hline Great Britain & 1.92 & 2.42 & 1.83 & 2.00 & 1.67 \\
\hline Czech Republic & 1.08 & 1.17 & 0.92 & 0.92 & 1.00 \\
\hline France & 2.00 & 1.91 & 1.64 & 1.91 & 1.67 \\
\hline Italy & 2.00 & 1.67 & 1.42 & 2.33 & 1.75 \\
\hline Russia & 2.64 & 2.42 & 3.42 & 2.55 & 2.27 \\
\hline The Netherlands & 2.33 & 2.42 & 2.08 & 2.33 & 2.00 \\
\hline Sweden & 2.42 & 2.75 & 2.75 & 2.36 & 2.27 \\
\hline Hungary & 2.00 & 1.75 & 1.91 & 2.18 & 2.09 \\
\hline Slovakia & 1.27 & 1.36 & 1.45 & 1.45 & 1.18 \\
\hline Spain & 2.64 & 2.45 & 2.27 & 2.73 & 2.73 \\
\hline Belgium & 2.27 & 2.36 & 2.27 & 2.27 & 2.09 \\
\hline The United States & 2.64 & 3.09 & 2.82 & 3.18 & 4.36 \\
\hline Ukraine & 2.36 & 3.09 & 3.09 & 3.00 & 1.45 \\
\hline Norway & 2.82 & 2.73 & 2.55 & 2.45 & 2.45 \\
\hline Austria & 2.55 & 2.64 & 2.27 & 2.36 & 2.18 \\
\hline Denmark & 2.27 & 2.45 & 2.18 & 2.18 & 2.18 \\
\hline Romania & 3.00 & 2.64 & 2.36 & 3.00 & 2.27 \\
\hline Lithuania & 2.00 & 1.82 & 2.09 & 2.00 & 1.73 \\
\hline Turkey & 3.36 & 2.64 & 3.00 & 3.27 & 3.18 \\
\hline Latvia & 1.91 & 1.73 & 1.91 & 2.00 & 1.73 \\
\hline China & 4.27 & 3.55 & 4.00 & 3.36 & 4.36 \\
\hline Belarus & 2.00 & 2.64 & 3.27 & 2.36 & 1.45 \\
\hline Switzerland & 2.45 & 2.09 & 1.82 & 2.27 & 2.36 \\
\hline Finland & 2.09 & 2.64 & 2.36 & 2.45 & 2.27 \\
\hline
\end{tabular}

Source: Own research. 
The aim of the pilot research was also to testify the questionnaire and the research assumptions. According to some respondents, the questionnaire was too complicated and too long. The managers did not want to answer the questions which were treated by them as embarrassing and breaching the privacy policy of the company. After the pilot research, the decision was undertaken that the questionnaire should be pared and simplified. It was deiced that the most proper technique of the planned quantitative research will be the direct interview.

\section{Conclusions}

The article presents the pilot research results on the importance of psychic distance in the process of Polish companies' internationalization. The whole research will be of quantitative nature and it will be conducted with the use of direct interview technique on the sample of 200 companies. It was decided that this technique will enable the best quality of research.

The pilot research was conducted on the sample of 18 companies. Most of the managers agreed that psychic distance exists; however, it has small impact on the process of Polish companies' internationalization. The respondents were asked about stimuli having impact on managerial perceptions of psychic distance. According to the majority of respondents, managerial perceptions of psychic distance depend on the international experience of managers, the knowledge of managers about international markets, the education of managers, and the stability and changeability of the environment, in which the company operates.

According to the managers, the most important factors having impact on decisions connected with internationalization are cultural differences (especially differences in religion), political differences (especially the level of democracy), geographic distance (the differences in time zones), and the differences in economic systems (the level of economic development).

The factors having impact on companies' engagement in international markets are the level of democracy, the level of infrastructure development, different way of thinking of managers, and differences in time zones.

According to the managers of the managers of the research, the countries most "far away" from Poland taking into consideration different psychic distance stimuli are India, Japan, China, Egypt, and other Arabic countries, Australia, and New Zealand. The countries "close" to Poland taking into consideration different psychic distance factors are Ukraine, Czech Republic, Slovakia, Russia, Germany, and France.

The managers stated that the most significant differences in cultural systems are among Poland-China, Poland-Turkey, and Poland-Romania. The most significant differences in economic systems between Poland and the receivers of Polish export are China, Ukraine, and the United States. The biggest differences in political systems are among Poland-China, Poland-Russia Belarus, and Poland-Ukraine. According to the managers, the biggest differences in mentality are among Poland-China, Poland-Turkey, and Poland-the United States. Geographic distance is the most important factor in Polish export to the United States, China, Turkey, and Spain. So, it can be observed that taking into consideration each of psychic distance stimuli, the biggest differences are between Poland and China.

According to the majority of respondents, the managers' perceptions about the significance of psychic distance in the process of companies' internationalization depend on managers' experience, managers' knowledge about international markets, the level of managers' education, and the level of stability and changeability of the environment the company operates.

The pilot research has been treated as the initial step to quantitative research, which will enable to testify the undertaking hypotheses. 
As the effect of the realization of the project, the theory about psychic distance will be settled. The main contribution of the solving this research problem to the international management and international business field will be the identification of the impact of the psychic distance dimensions on the decision making process connected with the internationalization of Polish companies. The effect of the project will be the development of the psychic distance measurement methodology and the methodology for research into the impact of psychic distance on the process of companies' internationalization (the methodology could be applied also in the international field). The research will also result in a model for measuring the impact of psychic distance on decision-making process related to internationalization of Polish companies. The research results will be treated as a hint to managers, how to engage in international activity. The research results will contribute to the development of international activity of Polish managers and to development of cooperation with foreign partners.

\section{References}

Beckerman, W. (1956). Distance and the pattern of inter-European trade. The Review of Economics and Statistics, 38(1), 31-40.

Bilkey, W. J., \& Tesar, G. (1977). The export behaviour of smaller Wisconsin manufacturing firms. Journal of International Business Studies, 8(1), 93-98.

Boyacigiller, N. (1990). The role of expatriates in the management of interdependence, complexity and risk of multinational corporations. Journal of International Business Studies, 21(3), 357-381.

Brouthers, K. D., \& Brouthers, L. E. (2001). Explaining the national cultural distance paradox. Journal of International Business Studies, 32(1), 177-190.

Carlson, S. (1974). International transmission of information and the business firm. The Annals of the American Academy of Political and Social Science, 412(1), 55-63.

Chang, S. J., \& Rosenzweig, P. M. (2001). The choice of entry mode in sequential foreign direct investment. Strategic Management Journal, 22(8), 36-56.

Clark, T., \& Pugh, D. S. (2001). Foreign country priorities in the internationalization process: A measure and an exploratory test on British firms. International Business Review, 10(3), 285-303.

Dow, D. (2001). A note on psychological distance and export market selection. Journal of International Marketing, 8(1), 41-62.

Dow, D., \& Karunaratna, A. (2006). Developing a multidimensional instrument to measure psychic distance stimuli. Journal of International Business Studies, 37(5), 578-602.

Dow, D., \& Karunaratna, A. (2009). Factors influencing perceptions of psychic distance. San Diego: Academy of International Business.

Dow, D., \& Larimo, J. (2009a). The impact of cultural distance framework on foreign establishment mode decision: Hofstede vs Schwarzt vs GLOBE. Proceedings from 35th EIBA Annual Conference Valencia, Spain.

Dow, D., \& Larimo, J. (2009b). Challenging the conceptualization and measurement of distance and international experience in entry mode choice research. Journal of International Marketing Research, 27(2), 74-98.

Dow, D., \& Larimo, J. (2011). Disentangling the roles of international experience and distance in establishment mode choice. Management International Review, 51(3), 321-355.

Drogendijk, R., \& Slangen, A. (2006). Hofstede, Schwartz, or managerial perceptions? The effects of different cultural distance measures on establishment mode choices by multinational enterprises. International Business Review, 15, 361-380.

Evans, J., \& Mavondo, F. T. (2002). Psychic distance and organizational performance: An empirical examination of international retailing operations. Journal of International Business Studies, 33(3), 164-168.

Fletcher, R., \& Bohn, J. (1998). The impact of psychic distance on the internationalization of the Australian firm. Journal of Global Marketing, 12(2), 47-68.

Grosse, R., \& Goldberg, L. G. (1991). Foreign bank activities in the United States: An analysis by country of origin. Journal of Banking and Finance, 15(6), 1093-1112.

Grosse, R., \& Trevino, L. J. (1996). Foreign direct investment in the United States: An analysis by country of origin. Journal of International Business Studies, 27(1), 139-155.

Håkanson, L., \& Ambos, B. (2010). The antecedents of psychic distance. Journal of International Management, 16(3), $195-210$. 
Harzing, A. W. (2002). Acquisitions versus Greenfield investments: International strategy and management of entry modes. Strategic Management Journal, 23(3), 211-227.

Holzmutter, H., \& Kasper, H. (1990). The decision-maker and export activity: A cross-national comparison of the foreign orientation of Austrian managers. Management International Review, 30(3), 217-230.

Johanson, J., \& Vahlne, J. E. (1977). The internationalisation process of a firm: A model of knowledge development and increasing foreign markets commitments. Journal of International Business Studies, 8(1), 23-32.

Johanson, J., \& Wiedersheim, P. F. (1975). The internationalisation of the firm: Four Swedish cases. Journal of Management Studies, 12(3), 305-322.

Kirkham, B. L., Lowe, K. B., \& Gibson, C. B. (2006). A quarter century of culture's consequences: A review of empirical research incorporating Hofstede's cultural values framework. Journal of International Business Studies, 37(3), 285-320.

Klein, S., \& Roth, V. J. (1990). Determinants of export channel structure: The effects of experience and psychic distance reconsidered. International Marketing Review, 7(5), 7-38.

Kogut, B., \& Singh, H. (1988). The effect of national culture on the choice of entry mode. Journal of International Business Studies, 19(3), 411-432.

Nordstrom, K. A., \& Vahlne, J. E. (1994). Is the globe shrinking? Psychic distance and the establishment of Swedish sales subsidiaries during the last 100 years. In M. Landeck (Ed.), International trade: Regional and global issues (pp. 41-56). New York: ST. Martin's Press.

Shenkar, O. (2001). Cultural distance revisited: Towards a more rigorous conceptualization and measurement of cultural differences. Journal of International Business Studies, 32(3), 519-535.

Shoham, A., Rose, G. M., \& Albaum, G. S. (1995). Export motives, psychological distance and the EPRG framework. Journal of Global Marketing, 8(3), 9-37.

Sousa, C. M. P., \& Bradley, F. (2005). Global markets: Does psychic distance matter? Journal of Strategic Marketing, 13(1), 43-59.

Sousa, C. M. P., \& Bradley, F. (2006). Cultural distance and psychic distance: Two pears in a pod? Journal of International Marketing, 14(1), 49-70.

Sousa, C. M. P., \& Bradley, F. (2008). Cultural distance and psychic distance: Refinements in conceptualization and measurement. Journal of Marketing Management, 24(5-6), 467-488.

Sousa, C. M. P., \& Lages, L. F. (2011). The PD scale: A measure of psychic distance and its impact on international marketing strategy. International Marketing Review, 2(2), 201-222.

Stottinger, B., \& Schlegelmilch, B. B. (2000). Psychic distance: A concept past its due date? International Marketing Review, 17(2), 169-173.

Tihanyi, L., Griffith, D., \& Russel, C. (2005). The effect of cultural distance on entry mode choice, international diversification, and MNE performance: A meta-analysis. Journal of International Business Studies, 36(3), 270-283.

Wiedersheim, P. F., Olson, H. C., \& Welch, L. S. (1978). Pre-export activity: The first step in internationalization. Journal of International Business Studies, 9(1), 47-58.

Zhao, H., Luo, Y., \& Suh, T. (2004). Transaction cost determinants and ownership-based entry mode choice: A meta-analytic review. Journal of International Business Studies, 35(6), 524-544. 